\title{
AOR
}

Selected Papers of \#AolR2021:

The 22nd Annual Conference of the

Association of Internet Researchers

Virtual Event / 13-16 Oct 2021

\section{COLONIALISM, INDEPENDENCE AND DIGITAL TECHNOLOGY}

\author{
Sophie Toupin \\ University of Amsterdam, the Netherlands
}

Nii Kotei Nikoi

The College of Wooster, United States

Admire Mare

Namibia University of Science and Technology, Namibia

Wendy Willems

London School of Economics and Political Science, United Kingdom

Conventionally, the African continent is largely written out of accounts on technology. If discussed, technology is often framed as the result of outside influences or the product of technology transfer from the West but rarely are Africans taken seriously as makers or active users of technology (Mavhunga, 2014, 2017). Recent work on race and technology has been useful in highlighting the contribution of Black people to the development of digital technology (Mcllwain, 2020) and the creative deployment of technology and Black joy (Brock, 2020) but has not always engaged extensively with longer histories of racialization and transnational dimensions of Blackness.

Ongoing debates on platform imperialism (Jin, 2013) and data colonialism (Couldry and Mejias, 2019) have been important in demonstrating the disproportionate levels of power that global social media platforms continue to wield and the lingering importance of technology in extractive practices. However, these political economy approaches insufficiently acknowledged spaces for agency in their analyses. Furthermore, in concentrating their focus on Big Tech, they have had little regard for the way in which the state - whether colonial or postcolonial - impinges on the everyday lives of citizens.

The four papers in this panel deploy the notion of independence to make sense of the way in which Africans have created, used and imagined digital technology. They consider digital technology as potential tools for liberation as well as constitutive of spaces that enable reflection on what it means to be independent. The panel treats the

Toupin, S., Nikoi, N. K., Mare, A., \& Willems, W., (2021, October). Colonialism, independence and digital technology. Panel presented at AolR 2021: The 22nd Annual Conference of the Association of Internet Researchers. Virtual Event: AolR. Retrieved from http://spir.aoir.org. 
freedoms occasionally made possible by digital technology as always subject to the constraints imposed by powerful actors such as the (post)colonial state and corporate social media platforms.

In contrast with the technologically advanced Apartheid state, the South African liberation movement is often framed as lacking technological innovation. However, the first paper demonstrates how in the 1980s, the African National Congress (ANC) Technical Committee developed a sophisticated encrypted communication system which was independent in the sense that it was neither developed to compete against other nations nor to gain market dominance. Instead, it was used to further liberation from a white supremacist regime.

The second paper examines digital cultural production as a site of decolonial praxis. Focusing on the case of Hiplife popular music in postcolonial Ghana, it argues that digital technology has constituted an important space which is independent from the hegemonic socio-spatial arrangements that continue to exclude many young people. These arrangements linger on from the historically racialized spatial segregation policies associated with the colonial period. Digital technology has enabled Hiplife musicians to share their music videos on YouTube in defiance of the ongoing social, political and economic barriers to accessing television platforms. In this way, they have built digital communities that produce new identities which disrupt colonial legacies.

Echoing the first two papers, the third paper acknowledges that digital technology such as social media platforms have opened up 'independent' spaces of participation for youthful protestors in Southern Africa to question state performance. However, the same platforms are increasingly vulnerable to state-ordered internet and social media shutdowns nor are they independent from the commercial and ideological imperatives of platform owners, who are often interested in profit maximization at the expense of engendering democratic spaces for political activism and deliberation. Ultimately, this demonstrates the double-edged nature of social media-driven protests in postcolonial Africa between the state and the platform.

The fourth paper discusses South African policy discourses around the Fourth Industrial Revolution (4IR) as postcolonial socio-technical imaginaries which are shaped by history and respond to larger global contexts. Technology and 'being modern' featured prominently in national imaginaries of the colonial state and continue to be important in postcolonial times. The paper examines how colonialism shaped the nature of South Africa's 4IR socio-technical imaginary and how it engaged with the legacy of colonialism and Apartheid and notions of freedom and independence. It argues that South Africa's policy discourses manifested a tension between disavowing colonial claims about Africa as the absence of technology and embracing a journey towards 'readiness' for an 4IR delivered by external forces.

\section{References}

Brock, A. L. (2020). Distributed blackness: African American cybercultures: New York, NY: New York University Press. 
Couldry, N. (2019). The costs of connection: how data is colonizing human life and appropriating it for capitalism. Stanford, CA: Stanford University Press.

Jin, D. Y. (2013). The construction of platform imperialism in the globalization era. TripleC 11(1): 145-172.

Mavhunga, C. (2014). Transient workspaces: technologies of everyday innovation in Zimbabwe. Cambridge, MA: MIT Press.

Mavhunga, C. (2017). What do science, technology, and innovation mean from Africa? Cambridge, MA: MIT Press.

Mcllwain, C. D. (2020). Black software: The Internet and racial justice, from the AfroNet to Black Lives Matter: New York, NY: Oxford University Press.

\section{THE AFRICAN NATIONAL CONGRESS (ANC) INTERNET DURING THE SOUTH AFRICAN LIBERATION STRUGGLE}

Sophie Toupin

University of Amsterdam, the Netherlands

This conference paper examines the development of the African National Congress (ANC) Internet during the South African anti-apartheid struggle. In the 1980s, the ANC Technical Committee developed a sophisticated independent and encrypted communication system that would be called in hindsight the 'ANC Internet'. This system, which was fully operational between 1988 and 1991, allowed freedom fighters on the ground in South Africa to communicate secretly and transnationally with the senior leadership of the African National Congress (ANC) based in Lusaka, Zambia via London, Great Britain. By focusing on the history of the ANC Technical Committee and its 'Internet', I recast the South African liberation struggle as part of the history of the pre-Internets and as part of a technological struggle, not absence. Methodologically, this paper is based on mixed data collection methods including empirical and archival materials conducted during my PhD research. Freedom fighters that developed and operated the encrypted communication system were interviewed through one-on-one semi-structured interviews in South Africa, the Netherlands, Canada and Great Britain. Archival research was also carried out in personal and publicly accessible archives in South Africa, the Netherlands and Great Britain.

The initial communication nexus of the ANC Internet was between Durban, London and Lusaka in 1988. It would later be operated from major cities in South Africa, namely, Cape Town, Durban, and Johannesburg as well as from Amsterdam, York, in Great Britain, TallCree, in Alberta, Canada and Harare. Dutch and Canadians who were active in the South African liberation movement at home and in South Africa were to play an important supportive role in the functioning of the ANC Internet, and in the transborder moving and on-site hosting of its equipment. In 1987, the communication system that was thought of in the late 1950s and which had been in development since the early 
1980s was integrated in Operation Vula. Vula was an operation that aimed to launch a people's war and bring back the exile leadership to South Africa to stir the machinery of mass movement to end the apartheid regime (O'Malley, 2007). Integrating the ANC Internet into Vula allowed for secret, strategic and transnational communication to further the goal of the people's war and minimized surveillance from the apartheid regime and the Five Eyes countries.

To shed light on the relationship between an independence struggle and technology, I first understand the South African liberation struggle in terms of a geography of technological struggle. In doing so, I challenge two long lasting stereotypes: the image of the South African liberation movement as defined by a lack of technological innovation; and of science and technology as being transferred to the South African liberation struggles from the Soviet Union during the Cold War. It is not this anti-colonial struggle that is remembered as technologically advanced outside of its use of radio (Lekgoathi, 2010; Lekgoathi, Moloi, \& Saíde, 2020); it is rather the apartheid apparatus. As part of its pressure tactics on and strategy to divest in the apartheid regime, the antiapartheid movements outside South Africa made claims that the apartheid regime was automating apartheid using advanced computer technology and called for a boycott of the sale of computers along with other technologies (NARMIC/American Friends Service Committee, 1982). By contrast, the story of the ANC Technical Committee and its contribution to the anticolonial struggle is not well known outside a handful of studies (Henderson, 1997; Garrett \& Edwards, 2007). Further, I demonstrate that while the Soviet Union and Cuba in particular were important in many ways for giving early trainings in radio and hand-written encryption, freedom fighters were cautious when it came to the internationalism of foreign powers. With archival material and interviews conducted during fieldwork, I reveal the words of members of the Technical Committee who argued that the USSR was not ready to give the South African freedom fighters their most sophisticated equipment but instead gave them their old discarded technical equipment. This is, in part, what motivated the ANC Technical Committee to build their independent encrypted communication system.

The expression the 'ANC Internet' was used in hindsight by one of my interviewees to describe the ANC Technical Committee achievement. Technically, the 'ANC Internet' meant that it connected a handful of computers operated by freedom fighters located on three continents using a pre-existing telecommunication infrastructure including the international phone system and telematics in Britain, the Netherlands, South Africa and Canada. The ANC Internet also meant the control over the means of communication production, and thanks to the secretive and encrypted nature of the system, it enabled protection against surveillance. Today, the expression the 'ANC Internet' resonates quite well with current discussions about technological, digital and network sovereignty used within social movements (Haché, 2014; Nitot, 2016) and indigenous groups (Duarte, 2017; Kukutai \& Taylor, 2016) among others.

The ANC Internet was independent in the sense that it was neither developed to compete against other nations or to gain market dominance, it was used to further liberation from a white supremacist regime. The communication system developed during the liberation struggle did not last after the apartheid regime fell. However, and it is important to mention, it is precisely because of their experiences with advanced 
technologies during the liberation struggle that the post-apartheid government (and particularly the South African police, military, and intelligence agencies) came to understand and appreciate the power of new technologies, particularly surveillance technologies, and use them in the post-apartheid era to spy on their population, particularly the poor, the workers, and students (Duncan, 2018).

\section{References}

Duarte, M. E. (2017). Network sovereignty: Building the internet across Indian country. Seattle, WA: University of Washington.

Duncan, J. (2018). Stopping the spies constructing and resisting the surveillance state in South Africa. Johannesburg: Wits University Press.

Garrett, R. K., \& Edwards, P. (2007). Revolutionary secrets: Technology's role in the South African anti-apartheid movement. Social Science Computer Review 25(1): 13-26.

Haché, A. (2014). La souveraineté technologique. Dossier Ritimo. Retrieved from https://www.ritimo.org/lMG/pdf/dossier-st1.pdf

Henderson, R. D. (1997). Operation Vula against Apartheid. International Journal of Intelligence and Counter Intelligence 10(4): 418-455.

Kukutai, T. \& Taylor, J. (2016). Indigenous data sovereignty: Toward an agenda. Canberra, Australia: ANU Press.

Lekgoathi, S. P. (2010). The African National Congress's Radio Freedom and its audiences in apartheid South Africa, 1963-1991. Journal of African Media Studies 2(2): 139-153.

Lekgoathi, S.P., Moloi, T. \& Saíde, A.R.S. (2020). Guerrilla radios in Southern Africa: Broadcasters, technology, propaganda wars, and the armed struggle. Africa: Past, Present \& Prospects. Lanham, Maryland: Rowman \& Littlefield.

NARMIC/American Friends Service Committee. (1982). Automating Apartheid: U.S. computer exports to South Africa and the Arms embargo. Philadelphia, PA.

Nitot, T. (2016). Numérique: reprendre le contrôle. Paris: Framasoft. Retrieved from https://framabook.org/docs/NRC/Numerique ReprendreLeControle CC-By impress.pdf

O'Malley, P. (2007). Shades of difference: Mac Maharaj and the struggle for South Africa. New York, NY: Penguin Books. 


\section{RECLAIMING AND REMAKING DIGITAL SPACE: POPULAR CULTURE AND DECOLONIAL CONSCIOUSNESS}

Nii Kotei Nikoi

The College of Wooster, United States

Cultural productions like Ghanaian hiplife - a transcultural musical form developed from U.S. hip hop and Ghanaian highlife - take up social space; as a consequence they reclaim and remake space. I argue that hiplife music and videos can become sites of decolonial praxis because, amongst other things, they necessarily involve the occupation of space, especially and increasingly through their presence in, and production of, digital space. Hiplife music making produces online spaces which are often independent from hegemonic socio-spatial arrangements that exclude many young people in postcolonial Ghana. How does hiplife occupy digital space and what possibilities are created for producing decolonial sensibilities, and hence decolonial identities?

There have been important arguments tracing ongoing imperial relations of domination enacted through digital technologies on postcolonial states (Couldry \& Meijas, 2019). Yet, I want to draw attention to the everyday micropolitics of digital making which can make legible, strategies that challenge what Anibal Quijano (2007) calls coloniality - the relations of domination (cultural, economic, and political) that continue after the formal 'ending' of colonization. Engaging in what Gibson-Graham (2008) calls a politics of possibility, I extend critical formulations such as data relations (Couldry \& Meijas, 2019), which through their representation of global capitalism as durable automatic structures, have the performative effect of obscuring the legibility of alternative economies (GibsonGraham 2008, p. 615). While these digital platforms are commodifying social relations, they also form the grounds for pioneering new politics of digital making.

In pursuing this line of argument, I also follow work that understands 'cyberspace' as not necessarily separate from so-called physical space, but as a transformation of preexisting social spaces (Moores 2004). Couldry and McCarthy's (2004) notion of mediaspace speaks to the way that media creates space while also being shaped by pre-existing spatial arrangements. Media systems have also operated as tools for establishing spatial ordering. Massey (2009, p. 17) argues that space is relational and "always in a process of being made". As such, it is open to change and hence a site of politics. Further, Frith (1996, p. 114) reminds us that music making and its consumption not only position us in the world but impact our sense of world making. He notes that sound is already involved in the process of transcending borders (across walls or hedges) and defining places (night clubs etc.). How do we use music to take us to a decolonial space?

We must recall that historically racialized spatial segregation policies in Ghana that segregated European residents from native residents contributed to definitions of 'Nativeness' and 'Europeanness' (Pierre, 2012). However, through Ghanaian highlife music, for instance, these colonialist definitions were challenged, engendering new identities that would reclaim and remake socio-spatial arrangements through the 
independence struggle. Highlife became an anti-colonial tool for independence through the way musicians indigenized their performances to align with Kwame Nkrumah's (Ghana's first president's) notion of "African Personality" and the ideology of PanAfricanism (Collins, 2005).

Today, due to an absence of a concerted national project aimed at confronting coloniality and engendering a decolonial consciousness, popular culture continues to present an opening. To be clear, post-Nkrumah governments seem to have disinvested in arts and culture - leasing Ghana Film Industry Corporation to Malaysian firm, TV3, limiting musical education in basic schools etc.- which has contributed to starving the Ghanaian imagination. ${ }^{1}$ Hiplife develops within this period of disinvestment in arts. Harold Cruse (1968), U.S. African American intellectual, argued that the cultural front presents relative independence to be original since it does not always involve the production of physical goods. In Ghana, young people on the margins of society use localized U.S. hip-hop tools and methods to cultivate collective agency and identities. bell hooks (1989, p. 19) reminds us that while interdependent with the whole, the margin is a "space of radical openness", possibility and resistance. Of course, a decolonial politics is not guaranteed but hiplife's relative independence makes it another site of possibility, of struggle (Hall, 1993).

Today, cultural producers involved in hiplife music and videos employ internet technologies to reshape social-spatial relations in several ways. Music videos allow artists to visualize the worlds they create in their music and invite viewers to inhabit that space. For instance, through "positive" representations artists challenge narratives of Africa as a space of negation. Examining audience comments on YouTube, one observes how these representations can engender pride and reattachment to the nation and continent.

Artists also share their music videos on YouTube partly because of barriers to accessing television platforms. In addition to requesting payments, television stations may ask for edits, make edits themselves or reject videos without providing any reason. Rappers also leverage social media for income and (re)producing their brand by cultivating an audience. Several young artists still live with their parents, and the fame and income allows them some economic independence which helps reduce conflict from parental pressures to pursue conventional occupations.

Music video directors also employ social media for: recruiting talent (especially women models from Instagram); sharing information amongst cast and crew of a project; building their brand; and learning. A model organizer informed me that she uses WhatsApp groups to share casting calls and to manage a team of models, essentially creating a virtual agency. Makeup artists, models and dancers also capture behind the scenes images of themselves and their work that they share online for self-promotion particularly when they work with well-known artists.

\footnotetext{
${ }^{1}$ See "Language Is a 'War Zone': A Conversation With Ngũgĩ wa Thiong'o" by Rohit Inani (2018) https://www.thenation.com/article/language-is-a-war-zone-a-conversation-with-ngugi-wa-thiongo/
} 
The presence of hiplife artists' music, videos, and embodied self-expressions trouble questions about young people's place in society, often questioning the various spatial arrangements that exclude many from national conversations. Recently when young Rastafarian teens were denied admission to the elite Achimota senior high school because they would not cut their locks, artists like Reggie Rockstone posted images of themselves with their locks and critiqued this racist colonial practice of exclusion around Black hair. In these ways, hiplife cultural producers are shaping how young people understand their place in postcolonial Ghana. At the same time, they are building digital communities inhabited by their fans in ways that produce new identities.

\section{References}

Collins, E. J. (2005). The decolonization of Ghanaian popular entertainment (pp. 119137). In: T. Falola and S. Salm (eds), Urbanization and African cultures. Durham, NC: Carolina Academic Press.

Couldry, N., \& McCarthy, A. (2004). Mediaspace: Place, scale and culture in a media age. London: Routledge.

Couldry, N., \& Mejias, U. A. (2019). Data colonialism: Rethinking big data's relation to the contemporary subject. Television \& New Media 20(4): 336-349.

Cruse, H. (2009) Rebellion or revolution? Minneapolis, MN: University of Minnesota Press.

Frith, S. (1996). Music and identity (pp. 108-127). In: S. Hall and P. Du Gay (eds.), Questions of cultural identity. London: SAGE Publications.

Gibson-Graham (2008). Diverse economies: performative practices for other worlds. Progress in Human Geography 32(5): 613-632.

Hall, S. (1993). What is this "black" in black popular culture? Social Justice 20(1/2)(5152): 104-114.

hooks, b. (1989). Choosing the margin as space of radical openness. Framework: The Journal of Cinema and Media 36: 15-23.

Massey, D. (2009). Concepts of space and power in theory and in political practice. Documents d'anàlisi geogràfica 55: 15-26.

Moores, S. (2004). The doubling of place: Electronic media, time-space arrangements and social relationships (21-36). In N. Couldry \& A. McCarthy (eds.), Mediaspace:

Place, scale, and culture in a media age. London: Routledge.

Quijano, A. (2007). Coloniality and modernity/rationality. Cultural Studies 21(2-3): 168178. 


\title{
SOCIAL MEDIA, ACTIVISM AND THE POSTCOLONIAL STATE IN SOUTHERN AFRICA
}

\author{
Admire Mare \\ Namibia University of Science and Technology, Namibia
}

This conference paper seeks to interrogate the extent to which independence can be conceptualized as away from the postcolonial state in the context of social media and activism in Southern Africa. Building on AoIR21's theme, independence for whom, from what, where, and under what constraints, this paper critically examines the extent to which social media has opened up 'independent' invented spaces of participation for youthful protestors in eSwatini, Mozambique, Malawi, Namibia, South Africa and Zimbabwe to question bad governance, poor service delivery, human rights violations and corruption. Cyber-optimists laud social media platforms for "levelling the playing field" by empowering otherwise powerless actors as well as acting as a crucial tool of political activism. Like the internet, social media platforms were initially glorified as alternative spaces through which activists could circumvent the encroaching levers of the postcolonial state in Africa as well as a break from the constraints of invited spaces of participation and traditional media. In ways, this paper jettisons taken-for-granted assumptions about the independence of social media platforms from political and economic power. It argues that although social media platforms have created relatively 'independent' spaces for horizontal, vertical and oblique voice for young activists in selected African countries, the same platforms are increasingly vulnerable to stateordered internet and social media shutdowns. Furthermore, social media platforms are not independent from the commercial and ideological imperatives of platform owners, who are often interested in profit maximization at the expense of engendering democratic spaces for political activism and deliberation.

In this paper, the notion of the 'postcolonial state' in Africa is conceptualized as characterized by continuities and ruptures. As Mbembe (2001) aptly puts it, the postcolonial state revolves around the way the world of meaning is ordered, the types of institutions, the knowledges, norms that structure this new 'common sense' as well as the light visual imagery and discourse throws on the nature of domination and subordination. This postcolonial state of affairs is made up of 'citizens' and 'subjects' (Mamdani, 1996), which bring different political subjectivities to bear on the actualization of the 'obscene and grotesque' in postcolonial Africa. Such a conceptualization acknowledges that institutions of the 'old' (colonial) regimes coexist with those of the new 'postcolonial' state. The paper critiques the taken for granted assumptions that the transition from the colonial political order occurred in a linear fashion (from an authoritarian order to a more democratic order). The nature of this postcolonial state in many cases is not radically different from the colonial state in terms of its governmentality, modes of operation, its administrative and bureaucratic practice and deployment of law and order strategies. As a result, the postcolonial state in Africa has been castigated for failing to listen to demands of ordinary people. Unsurprisingly, most social protests in the last decade in Southern Africa have been linked to deep-seated frustration with the continued high levels of unemployment, inequality and a revolt against a postcolonial state that is increasingly seen as uncaring, lethargic and not 
listening (Wasserman and Garman, 2014). This is more pronounced where young people are marginalized by political and social structures (Garman \& Malila, 2016). Therefore, crisis of expectations, hopelessness and discontent amongst youthful citizens in Southern Africa have been singled out as some of the key factors in social protests, which are often organized and choreographed on social media platforms.

In terms of data collection techniques, the study deploys digital ethnography (online participant observation), qualitative content analysis and in-depth interviews with youth activists in selected Southern African countries. The paper also reveals that youth activists in Southern Africa used social media in their own unique ways as shaped and dictated by the broader political and mediated opportunity structures (Mare, 2016). It argues that youth's engagement with social media platforms for political purposes should be understood in their own terms without necessarily imposing inflexible boundaries on what counts as political participation. Although social media platforms foster avenues for cognitive engagement, discursive participation and political mobilization, these political practices are not immune to the influences of offline processes. This study argues that social media platforms should be viewed as a 'sites of power' where corporate forces and platform-specific code coalesce together fostering 'algorithmic' gatekeeping practices and the favoring of paid-for-content over non-paid for user-generated-content which ultimately affects activists' visibility and reach within the digital media ecology (Mare, 2016). These gatekeeping practices therefore further undermine claims by cyber-optimists that social media platforms are the sine qua non spaces for symmetrical and democratic participation. It also argues that 'subtle forms of control' characterize the much-glorified participatory cultures on social media in ways that defy optimistic accounts of the role of digital media in political change.

Despite the realization that social media platforms are caught up within webs of control structures, which makes them vulnerable spaces to communication surveillance, internet shutdowns and trolling, youth activists trapped in oppressive political contexts are still using them as spaces of last resort in terms of consensus mobilization. This paper also problematizes the arbitrary use of floating signifiers like 'independence' and 'free speech' by youth activists to justify the circulation of hurtful and hateful speech on social media platforms. It questions the popularization of retrogressive politics in the name of 'independence' and freedom of expression especially through the strategic deployment of cyber-troops such as Varakashi and Nerrorists in countries such as Zimbabwe. Similarly, issues such as cyber-bullying, gender-based violence against women, hate speech and disinformation have taken center stage in South Africa, Namibia, eSwatini and Malawi. Drawing on empirical data from viral hashtag movements such as \#ZimbabweanLivesMatter, \#Tajamuka, \#ShutltAllDown, \#NakedProtest and so forth, this paper highlights the double-edged nature of social media-driven protests in postcolonial Africa.

\section{References}

Garman, A., \& Malila, V. (2016). How South Africa's media deny youth a voice? The Conversation. Retrieved from http://theconversation.com/how-south-africas-mediadeny-the-countrys-youth-a-voice-54853 
Mamdani, M. (1996). Citizen and subject: contemporary Africa and the legacy of late colonialism. Princeton, NJ: Princeton University Press.

Mare, A. (2016). Facebook, youth and political action: a comparative study of Zimbabwe and South Africa. PhD dissertation, Rhodes University, South Africa.

Mbembe, A. (2001). On the postcolony. Berkeley, CA: University of California Press. Wasserman, H., \& Garman, A. (2014). The meanings of citizenship: media use and democracy in South Africa, Social Dynamics: A Journal of African Studies 40(2): 392407.

\title{
POSTCOLONIAL SOCIO-TECHNICAL IMAGINARIES AND THE FOURTH INDUSTRIAL REVOLUTION
}

\author{
Wendy Willems \\ London School of Economics and Political Science, United Kingdom
}

The aim of the Fourth Industrial Evolution (4IR) is the transformation of existing business models through the adoption of a range of digital technologies such as 3D printing, artificial intelligence (Al), autonomous vehicles, biotechnology, cyber-physical systems (CPS), fifth-generation wireless (5G), internet of Things (IoT), industrial Internet of Things (IloT), nanotechnology, quantum computing and robotics (Schwab, 2017). The World Economic Forum (WEF), and its executive chairman Klaus Schwab, is a key driver of the 4IR agenda. This agenda has obtained a renewed relevance in the context of the COVID-19 pandemic as part of the WEF's 'The Great Reset' proposal which includes resetting labor markets in response to the pandemic-induced growth of remote work. The upskilling and reskilling of workers required in preparation for the 4IR is linked to this 'reset'. Ultimately, COVID-19 has resulted in accelerating the push for the adoption of 4IR technology, which will enable Big Tech to accumulate even more power and exert control globally.

South Africa's President Cyril Ramaphosa enthusiastically embraced WEF's 4IR agenda when he took office in February 2018, suggesting that it was a development that was both inevitable and desirable, expected to reap positive benefits for the continent (Kaisara et al, 2021: 67). This quickly provoked a heated debate in South Africa, ranging from hopes about a better future to critical voices expressing concerns about the anticipated job losses from automation and robotization in a country faced with high rates of unemployment. A number of institutions were set up to help coordinate the 4IR such as the Presidential Commission for the Fourth Industrial Revolution and the South African Centre for the Fourth Industrial Revolution (C4IR SA), an affiliate center of the WEF's C4IRs. Universities were quickly accorded an important role in implementing the $4 \mathrm{IR}$ agenda, both in terms of carrying out research on the various technologies associated with $4 \mathrm{IR}$ and in providing students with the required skills. 
This paper frames South Africa's policy discourse around 4IR as a postcolonial sociotechnical imaginary and situate this in a longer, historical discourse on technology. Sociotechnical imaginaries refer to "collectively held, institutionally stabilized, and publicly performed visions of desirable futures, animated by shared understandings of forms of social life and social order attainable through, and supportive of, advances in science and technology" (Jasanoff, 2015: 4). Narratives about 4IR and artificial intelligence often deploy "a rhetorical use of the future, imagining that present shortcomings and limitations will shortly be overcome" (Natale and Ballatore, 2020: 3). They also provide a "crucial epistemic site for exploring contemporary debates about these powerful new technologies" (Cave et al, 2020: 1).

Sociotechnical imaginaries are national imaginaries which are shaped by history and respond to larger global contexts. Technology and 'being modern' featured prominently in national imaginaries of the colonial state. For example, Cecil John Rhodes, the colonial ruler in Southern Africa, imagined South Africa as a nation "with profitable industries based on progressive engineering, racial segregation, and corporate surveillance, all sanctioned by a unified state" (Storey 2015: 53). Technology was an important part of the colonial encounter. The gun was essential in the creation of racial discrimination in South Africa in the seventeenth, eighteenth and nineteenth century (Storey 2008) while centralized fingerprint identification was essential to the late nineteenth and twentieth century Apartheid state (Breckenridge 2014). However, of course, technology in Africa was not merely the result of outside influences or the product of technology transfer from the West (Mavhunga, 2017). Such an assumption would in itself be a colonial construction. Africans made crucial contributions to the creation of technology and scientific knowledge which have often been deliberately obscured and silenced in colonial accounts (Mavhunga, 2014).

Discourses on modernization and the role of technology in this process continue to be important in postcolonial times. South Africa's black majority population obtained independence in 1994 during a time of globalization and the adoption of neoliberal policies worldwide. Unlike other decolonized nations on the African continent and in other parts of the Global South, which adopted economic policies of self-reliance and import-substitution industrialization immediately after obtaining independence, South Africa's transition to 'freedom' saw the country opening up to foreign investment and neoliberal market reforms. This prevented radical economic reforms such as land redistribution from taking place and saw a continuation of economic inequalities along racial lines. While during Apartheid, South Africa was shielded from global scientific networks and developed its own scientific journals, it was keen in 1994 to re-engage globally. Technology and science were a crucial part of Thabo Mbeki's 'African Renaissance' which proposed the stimulation of "indigenous African knowledge systems alongside 'blue skies' global science" (Dubow 2019: 684). This paper demonstrates that South Africa's sociotechnical imaginary should be understood within this longer historical context.

Methodologically, the paper draws on a critical discourse analysis of South African government policy documents, government speeches and think tank policy reports on the 'Fourth Industrial Revolution' published between February 2018 and June 2021. In the paper, I ask the following questions: What does the Fourth Industrial Revolution 
mean in the specific context of South Africa? How has colonialism shaped the nature of this socio-technical imaginary and how does this imaginary engage with the legacy of colonialism and Apartheid and notions of freedom and independence? What problems does technology promise to address in South Africa's 4IR discourse? How is the adoption of 4IR technology legitimized and justified? How does South Africa's 4IR discourse reflect its engagement with the Global North and with the African continent?

The paper argues that South Africa's policy discourses manifested a tension between disavowing colonial claims about Africa as the absence of technology and embracing a journey towards 'readiness' for an 4IR delivered by external forces. Policy documents presented the 4IR as a succession to earlier technological contributions of precolonial states such as the Mapungubwe empire (a Southern African state located in presentday South Africa, Botswana, Zimbabwe, and Mozambique) in the area of gold mining However, the focus on 'preparedness' in much of the discourse around the Fourth Industrial Revolution implied that it was a period of technological change that was brought onto South Africa instead of driven by the country endogenously.

\section{References}

Breckenridge, K. (2014). Biometric state: the global politics of identification and surveillance in South Africa, 1850 to the present. Cambridge: Cambridge University Press.

Cave, S., Dihal, K., \& Dillon, S. (2020). Al narratives: a history of imaginative thinking about intelligent machines. Oxford: Oxford University Press.

Dubow, S. (2019). 200 years of astronomy in South Africa: from the Royal Observatory to the 'Big Bang' of the square kilometre array. Journal of Southern African Studies 45(4): 663-687.

Jasanoff, S. (2015). Future imperfect: science, technology, and the imaginations of modernity (pp. 1-33). In S. Jasanoff \& S.-H. Kim (rds.), Dreamscapes of modernity: sociotechnical imaginaries and the fabrication of power: Chicago: University of Chicago Press.

Mavhunga, C. (2014). Transient workspaces: technologies of everyday innovation in Zimbabwe. Cambridge, MA: MIT Press.

Mavhunga, C. (2017). What do science, technology, and innovation mean from Africa? Cambridge, MA: MIT Press.

Natale, S., \& Ballatore, A. (2020). Imagining the thinking machine: Technological myths and the rise of artificial intelligence. Convergence 26(1): 3-18.

Schwab, K. (2017). The Fourth Industrial Revolution. London: Penguin

Storey, W. K. (2008). Guns, race, and power in colonial South Africa. Cambridge: Cambridge University Press. 
Storey, W. K. (2015). Cecil Rhodes and the making of a sociotechnical imaginary for South Africa (pp. 34-55). In S. Jasanoff \& S.-H. Kim (eds.), Dreamscapes of modernity: sociotechnical imaginaries and the fabrication of power. Chicago: University of Chicago Press. 